\title{
Retightening Revision of a Previous MACS-Lift Meloplasty
}

\author{
Patrick Tonnard · Alexis Verpaele
}

Published online: 28 January 2010

(c) Springer Science+Business Media, LLC and International Society of Aesthetic Plastic Surgery 2010

We have read with interest the letter of Brigid Corrigan, William McMillan, and Morris Ritz from the Melbourne Institute of Plastic Surgery regarding the possibility of retightening a revisional MACS-lift surgery when permanent loop suture material is used. We encountered the same situation when revising one of our earlier MACS-lift patients from before 2002. In that case, we indeed used Prolene 2-0 in loop sutures [1]. We also were tempted to retighten the original suture but were disappointed in the effect we obtained in the neck. We are convinced that a strong vertical pull on the lateral part of the platysma produces a good correction of the cervicomental angle. We also know that all permanent suture material eventually will cheesewire through soft tissue, including muscle such as the platysma muscle. For this reason, we decided to switch from permanent suture material such as Prolene or nylon toward slowly resorbing material such as PDS [2].

Currently, we take two to three strong bites in the platysma muscle with the heavy PDS 1 suture to provide a strong grip on the muscle. This together with skin redraping and excision in the same vertical direction works as a lock on the neck and cheek sculpturing. From a series of more than 850 cases over the past 10 years, we have started redoing our initial cases $(n=7)$. We are happy that we can leave our patients without any permanent suture material to extrude over the years.

\section{References}

1. Tonnard P, Verpaele A et al (2002) Minimal access cranial suspension lift: a modified S-lift. Plast Reconstr Surg 109:20742086

2. Tonnard P, Verpaele A (2007) Short-scar face lift: operative strategies and techniques. Qualitiy Medical Publishing, St. Louis, MO
P. Tonnard $(\varangle) \cdot$ A. Verpaele

Coupure Centrum voor Plastische Chirurgie, Coupure Rechts

164 C-D, 9000 Gent, Belgium

e-mail: patrick@coupurecentrum.be 